\title{
Hauterivian shallow marine calcareous biogenic mounds: S.E. Spain
}

\author{
Consuelo Arias ${ }^{\text {a }}$, Jean-Pierre Masse ${ }^{\mathrm{b}}$, Lorenzo Vilas ${ }^{\mathrm{a}}$ \\ - Departamento de Estratigrafí, Instituto de Geologia Económica (CSIC-UCM), Universidad Complutense, 28040 \\ Madrid, Spain \\ ${ }^{b}$ Centre de Sédimentologie/Paléontologie, URA 1208 du CNRS, Université de Provence, 13331 Marseille Cedex 3, \\ France
}

\begin{abstract}
Hauterivian biogenic deposits from the Prebetic northern margin near Caudete (Albacete Province, southeastern Spain) are represented by low domed bodies, less than $10 \mathrm{~m}$ thick, surrounded by bioclastic sediments and capped by siliciclastics. They consist of a coral, stromatoporoid and microbial framework with cavities filled by mud, rapidly lithified. Intermound bioclastics, derived from the mound organic community, reflect high energy conditions and shallow water settings. Mound growth and architecture were controlled by nutrient fluxes and internal light gradients. Comparisons with closely related structures from the Palaeozoic and the Recent show some similarities but also significant differences; the example documented here also departs from other Cretaceous occurrences.
\end{abstract}

\section{Introduction}

Cretaceous shallow marine, calcareous, biogenic mounds either reported as reefs or mud-mounds are mainly documented from the Mediterranean and Caribbean regions. Whereas skeletal dominated frameworks are characterized by corals or bivalve rudists, non skeletal buildups are essentially related to mud mounds and/or microbial bioherms (Masse and Philip, 1981; Scott, 1988; Camoin et al., 1988; Negra and Purser, 1989; Pascal and Przybyla, 1989; Fernández-Mendiola and García-Mondéjar, 1989; Scott et al., 1990).

The purpose of this contribution is to illustrate biogenic mounds of early Hauterivian age first recorded by Vilas et al. (1982). Because very few examples of lowermost Cretaceous biogenic mounds have been documented till now (Scott, 1988; Jansa et al., 1982) the present study was achieved and deals with the following aspects:

- geographical and geological setting, including biostratigraphic context,

- stratigraphic setting,

-mound description including: morphology and size, internal structure and its biological content, lateral and vertical zonation,

-intermound sediments,

- palaeoenvironment and importance of early diagenesis,

- comparisons with closely related structures, from the geological record and from Recent environments. 


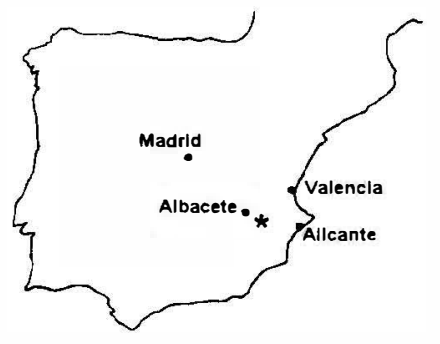

a)
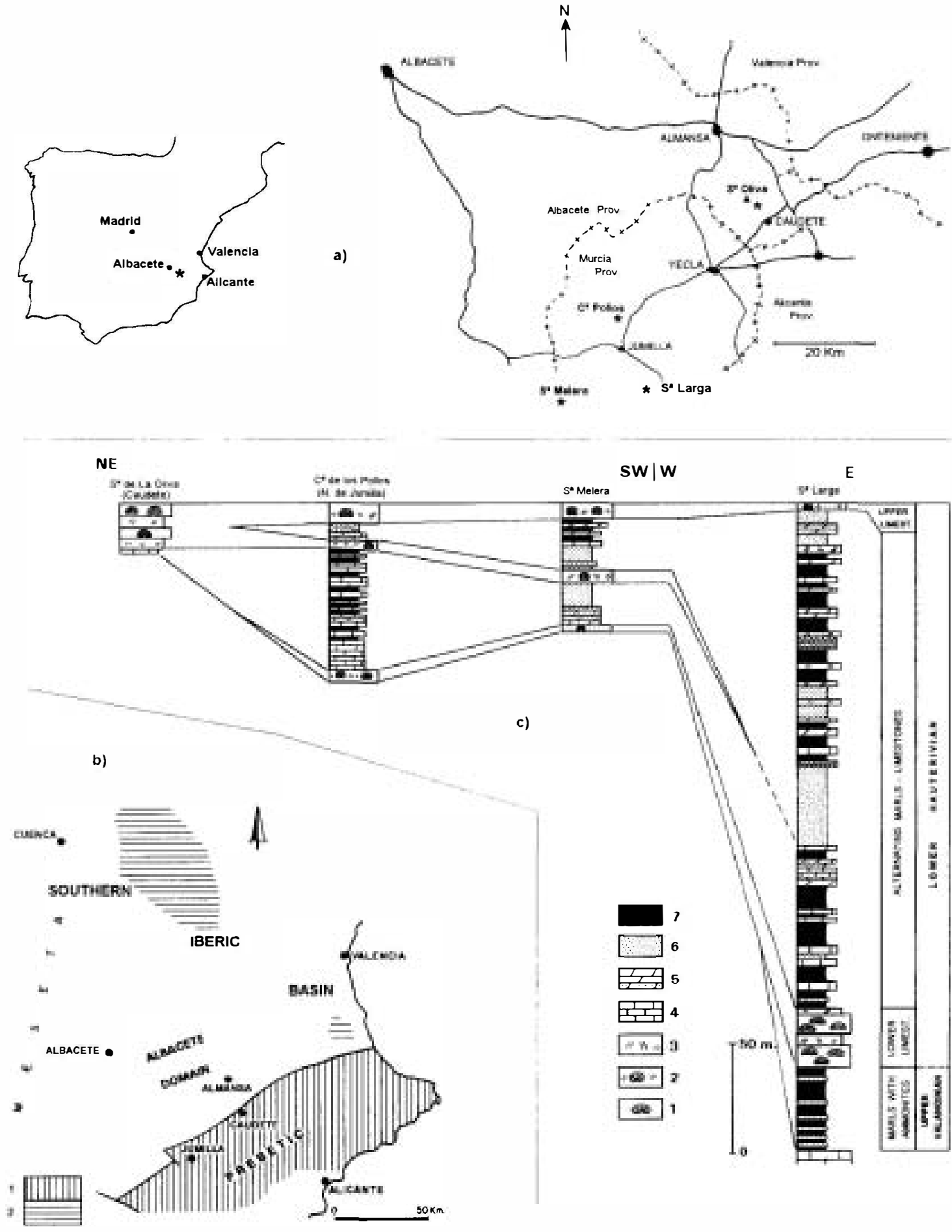

c)

SW $\mid \mathbf{W}$

E

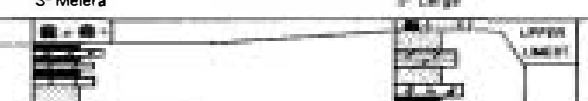




\section{Geographical and geological setting}

The studied area is situated in the Sierra de la Oliva, in the SE of Spain, near the SE boundary of Albacete Province, between the cities of Caudete and Almansa (Fig. la). This zone is located in the Betic structural zone, at the northern boundary with the tectonically stable Meseta zone. This boundary is represented by an important reverse fault that separates the two tectonic domains.

During the early Cretaceous, prior to the late Barremian-early Aptian transgression, the studied area was adjacent to a northward emerged domain (including both the Meseta and the Albacete regions) i.e. in proximal position relatively to the Betic sedimentary basin southwards.

Northwards, in the Southern Iberic Basin, there are, locally, littoral sediments of this age (Mas, 1981; Mas et al., 1982; Perez del Campo and Zabala, 1982) (Fig. 1b).

The investigated sediments pertain to a Upper Valanginian-Lower Hauterivian succession (Fig. 1c) developing in the Caudete-Jumilla region in three shallowing upward, northward onlapping sequences (Masse et al., 1993a). In the Sierra de la Oliva the lowest sequence is missing. The $24 \mathrm{~m}$ thick section unconformably overlies limestones and marls with siliciclastic beds, ascribed to the Berriasian, and is capped by sandstones of late Hauterivian age (Masse et al., 1993b). The Sierra de la Oliva section was described by Fourcade in 1970. The studied interval named "Upper bioconstructed limestones" after Masse et al. (1993) was presented by Vilas et al. (1982) as possibly Valanginian. The corresponding unit is now ascribed to the early Hauterivian, an age assessment based on the occurrence of: Meandrospira favrei (Charollais et al.), Trocholina molesta Gorbatchik, Choffatella decipiens Schlumberger, Suppiluliumaella cf. tubifera (Nikler and Sokac),
Neomeris sp. and Pachytraga tubiconcha Astre (Masse et al., 1993b).

\section{Stratigraphic setting}

The Sierra de la Oliva section shows two broad sequences (Fig. 2). The lower sequence starts with a ferrugenous, nearly horizontal, irregular surface truncating the top on the underlying Berriasian beds. The lower part $(6 \mathrm{~m})$ consists of alternating marly limestones and packstones-grainstones with some corals, in a bioclastic or locally oolitic matrix containing bryozoan, echinoderm and bivalve fragments and foraminifera (Lituolidae and Lenticulina). The upper part is a massive carbonate unit $(5 \mathrm{~m})$ with scleractinian corals and stromatoporoids in a wackestone matrix, locally grainy. This unit is split in its middle by a bioclastic packstone-grainstone with: coral, bryozoan, dasyclad and coralline algal fragments, and is capped by another bioclastic bed ending with a planar ferrugenous surface.

The upper sequence starts with cross-bedded, coarse-grained calcarenitic, bioclastic grainstones, containing green algal, echinoderm and bivalve fragments and foraminifera (Neotrocholina, Lituolidae, Meandrospira). Its thickness is $4-5 \mathrm{~m}$. The upper part corresponds to the biogenic mounds and associated sediments, herein described.

Cross-bedded siliciclastic sandstones drape the mounds and intermound sediments and locally contain limestone clasts or reworked fossils derived from the mounds.

\section{Characters of the biogenic mounds}

\subsection{External shape (Fig. 3)}

Outcrop observation allows us to trace a mound rich horizon, over a distance of $2 \mathrm{~km}$, where indivi-

Fig. 1. Location map, palaeogeographic sketch and stratigraphic sections of the studied sediments. (a) General location of the Sierra de la Oliva outcrop and the other studied sections (b). Sketch map for the SE Spain region showing the occurrence of the Upper Valanginian-Lower Hauterivian sediments; 1 = Betic basin with marine sediments, 2 = Southern Iberic basin with continental and coastal sediments. (c) General cross-section of the studied interval showing sequence organization and the broad constituent facies; $1=$ carbonate buildup, $2=$ bioclastic limestones, $3=$ grainstones, $4=$ marly limestones, $5=$ dolomitic limestones, $6=$ fine sands, $7=$ marls and clays. 


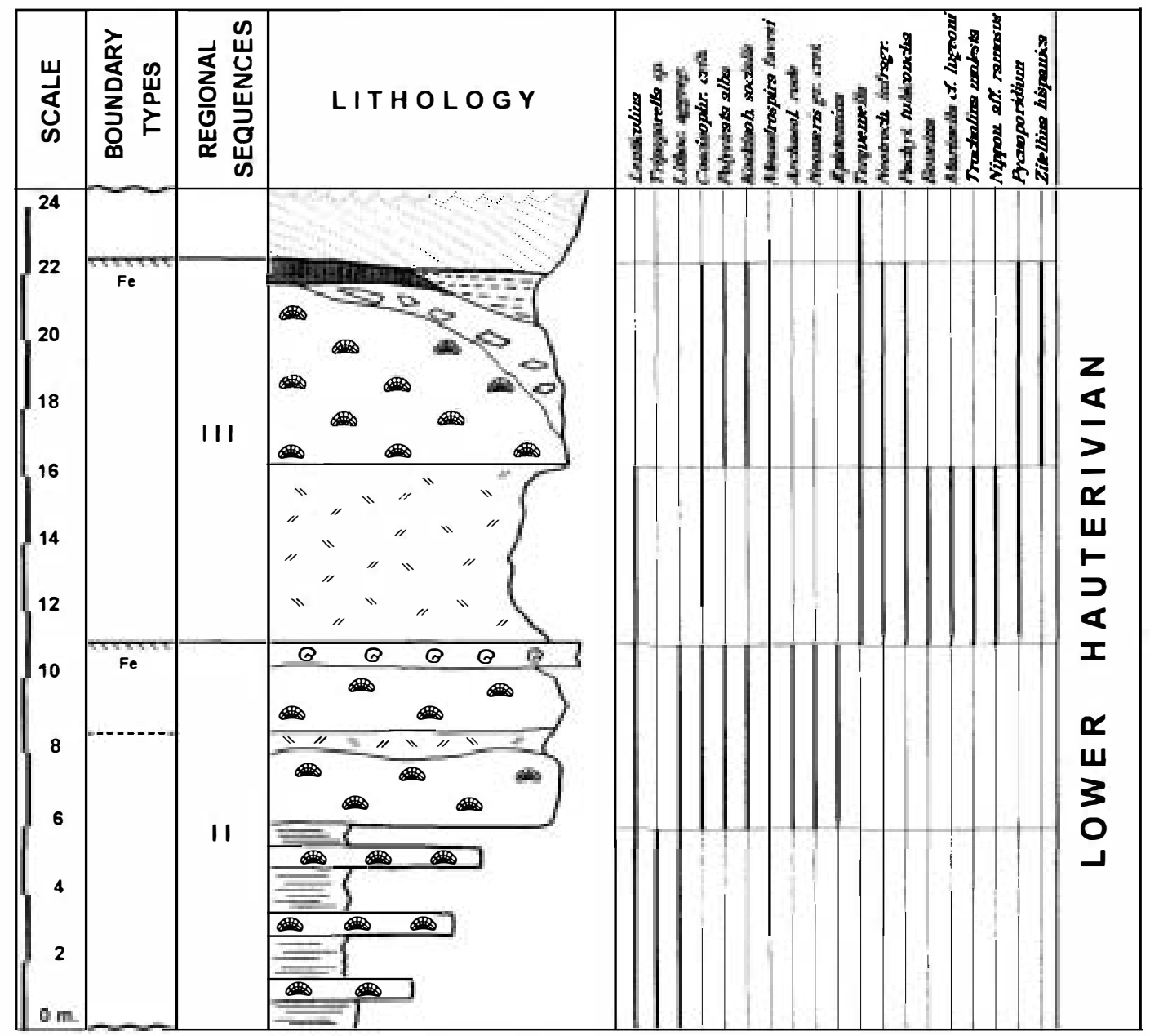

Fig. 2. Stratigraphic column of Sierra de la Oliva. Legend: see Fig. 3.

dual mounds are rare, being commonly linked together by their base. Vertical cross-sections show that the mounds have thicknesses from a few to 6-8 $\mathrm{m}$, a domal shape and basal dimensions between 12 and $18 \mathrm{~m}$. Dome flanks are nearly flat or slightly convex with highly variable slope angles from 10 to $40^{\circ}$. Three-dimensional reconstructions are speculative because of outcrop limitations. We tentatively consider the domes as more or less subcircular bodies in plan. The horizontal and planar bases show signs of erosion and evidence for early leaching which implies subaerial exposure. The buildups therefore developed on truncated/emersion surface.
Depositional relief from the surrounding sea floor was probably less than a few meters.

\subsection{Biological content and internal structure}

The mounds are massive carbonate bodies possessing decimeter-sized scattered colonies of corals and stromatoporoids embedded in a micritic matrix (Fig. 4). Rudists and gastropods are also present but are subordinate.

Corals show representatives of the following families: Microsolenidae, Thamnasteriidae, Stylinidae (Morycowa, work in progress). Stromatoporoids and chaetetids are relatively 

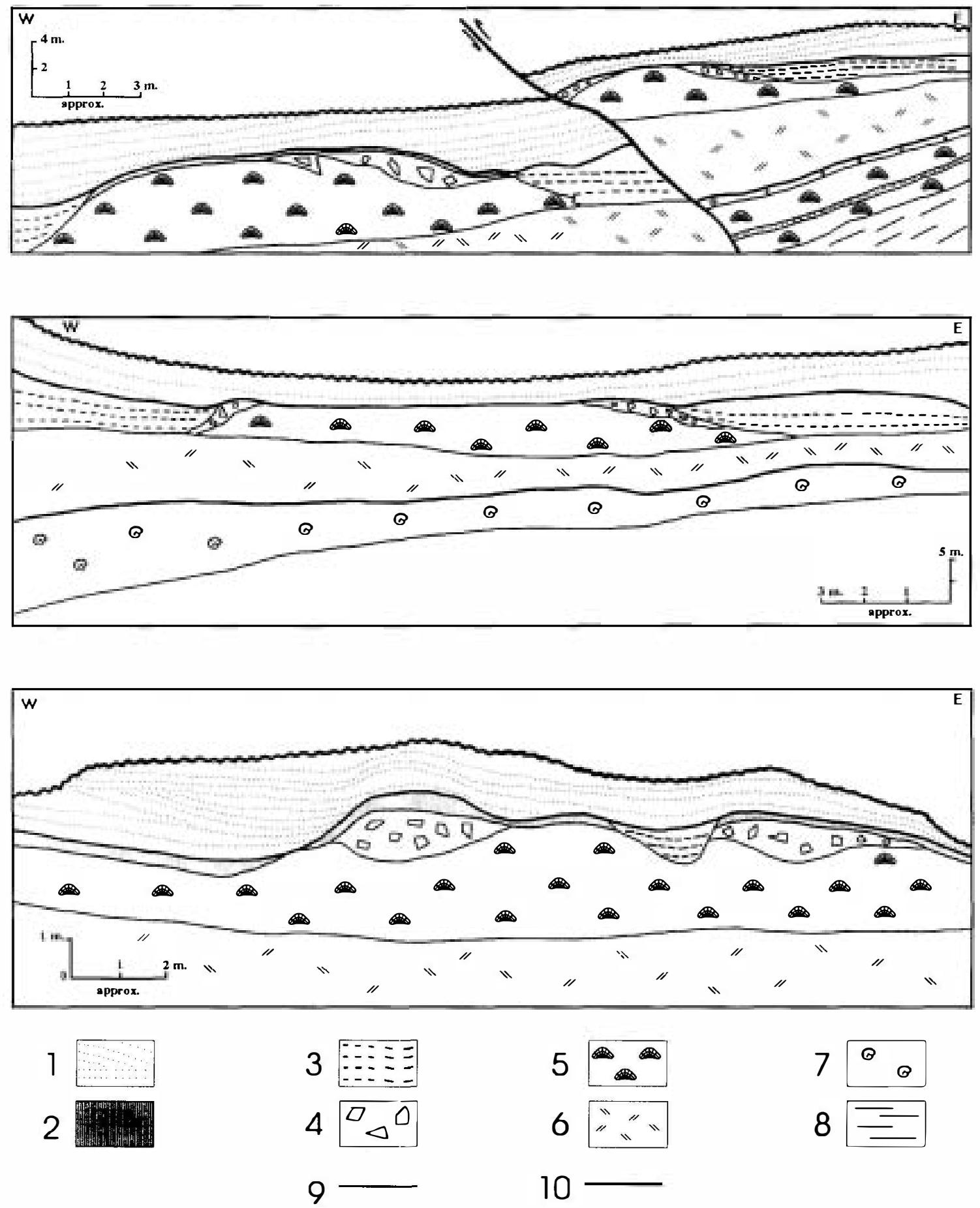

6 " $" 1$

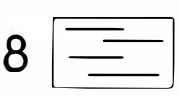

Fig. 3. Detailed sketch-sections of the different mounds of the Sierra de la Oliva outcrop. Based on outcrop photographs. $1=$ cross-bedded calcareous sandstones. 2 = altered clast-supported breccias; containing clasts of limestone mounds. $3=$ cross-bedded sandy grainstones. $4=$ flank breccias. $5=$ carbonate mud-core. $6=$ grainstones. $7=$ gastropod wackestones. $8=$ alternating marl-limestone with massive corals. $9=$ Facies boundary. $10=$ Alteration surface. 

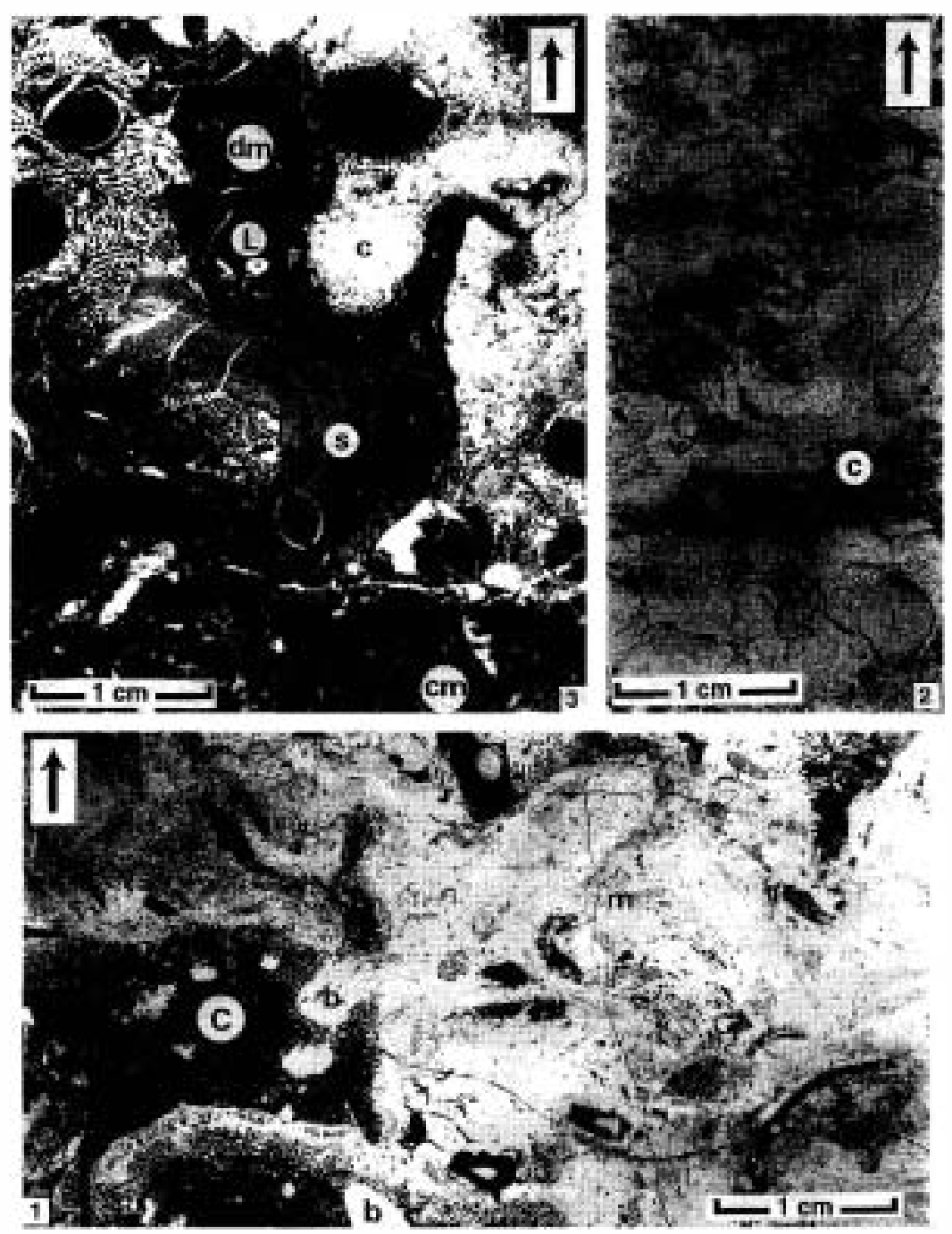

Fig. 4. Biogenic mound facies. 1. Polished slab showing the coral skeletal framework $(c)$ and the laminated associated micritic matrix $(m)$ with scattered rudist fragments $(r),(b)$ borings filled with micritic sediment. 2. Polished slab showing a densely bored coral $(c)$, skeletal framework, and in situ lithophagid shells $(L)$ filled with micritic sediment. 3. Thin section showing the coral $(c)$, stromatoporoid $(s)$ skeletal framework with lithophagid borings $(L)$, a dense micritic coating $(d m)$, also bored, and a clear micritic sediment $(\mathrm{cm})$. Arrow points out the direction of upward growth.

diverse but their precise identification still needs to be achieved. Rudists are illustrated by poorly defined requieniids and Pachytraga tubiconcha (Fig. 5.6). Calcareous sponges belonging to Corynella (Fig. 5.5) and Barroisia are not uncommon. Sponges are also represented by spherical and acicular spicules, the latter sometimes preserved in situ as a framework in a micritic matrix
(Fig. 5.2). Both types were initially siliceous and are preserved as secondary calcitic spar. The spherical spicules are frequently aggregated in the walls of coscinophragmatid foraminifera (Fig. 5.3). These spicules are ascribed to the family Geodidae. Recent examples having been reported on coral reef slopes (Macintyre, 1977). Lithophagid bivalves are common, locally abundant (Fig. 4.2). 


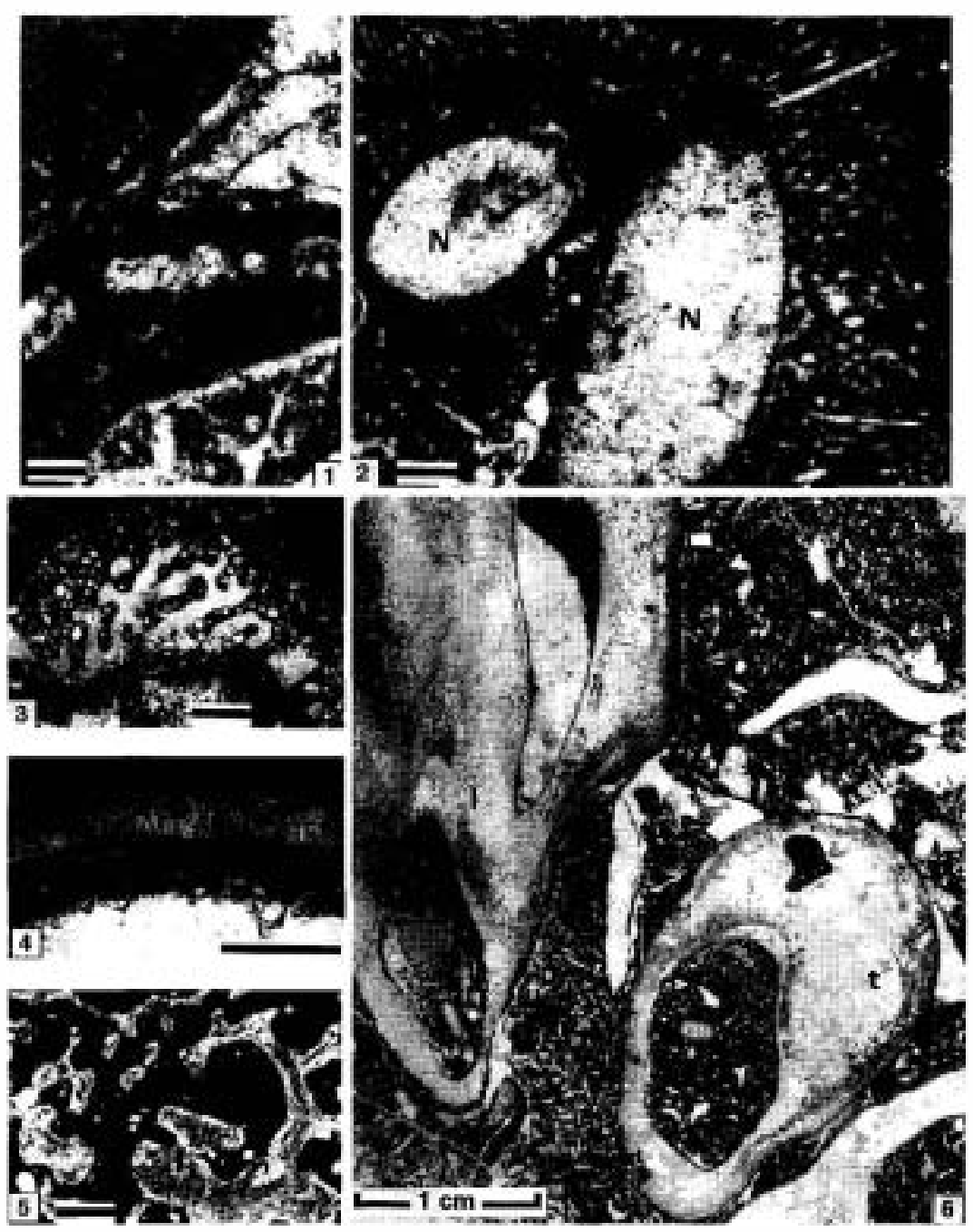

Fig. 5. Biogenic mounds : biologic skeletal components. 1. Archaeolithothamnium rude, $r=$ reproductive cavities. 2. Nipponophycus $(N)$ encrusted by a sponge spicule network. 3. Coscinophragma cribosum. 4. Polystatra alba. 5. Calcareous sponge tentatively ascribed to Corynella. 6. Rudists : Pachytraga tubiconcha, longitudinal $(l)$ and transverse $(t)$ sections of attached (right) valves, in a bioclastic muddy matrix. Scale bar is $0.5 \mathrm{~mm}$.

Brachiopods are only locally present. The occurrence of small encrusting forms (Thecididae) is to be noticed. Skeletal microbiota includes encrusting bryozoans, calcareous algae: Polystrata alba (Pfender) (Fig. 5.4), Archaeolithothamnium rude (Lemoine) (Fig. 5.1), Nipponophycus cf. ramosus (Yabe and Toyama), Koskinobullina socialis Cherchi and Schroeder (a problematicum ascribed to the Wetheredellaceae, Chlorophyta, by Barattolo, 1991), porostromatic cyanophytes, in particular the Bacinella irregularis RadoičićLithocodium aggregatum Elliot association, foraminiferas: coscinophragmatids, Bullopora and other poorly defined calcareous encrusting forms (e.g. nubecularids). Coscinophragmatids which play the major role are tentatively ascribed to Coscinophragma cribosum (Reuss) (Fig. 5.3). Their organization and encrusting habit are very similar to those from Bdelloidina urgonensis Wernli and Schulte which is a significant framebuilder in the 
Urgonian of SE France (Schulte et al., 1993; Wernli and Schulte, 1993). Different kinds of annelids are also recorded. Echinoderms and nonencrusting algae are present as fragments in the sediment matrix. Dasyclads are represented by: Carpathoporella fontis (Patrulius), Zittelina hispanica Masse et al. and Terquemella. Caulerpales are illustrated by the genus Boueina.

All the macrofaunal elements both sessile and mobile, may act as substrate or nuclei for stromatolitic encrustations, which consist of millimeterthick crusts, the laminae of which pertain to two main types :

(1) Dense finely laminated micritic crusts as well as closely related pelletoidal structures which are ascribed to the calcification of microbial mats, including both bacteria and cyanobacteria (Fig. 6). The term "pelletoidal" is used after Blatt et al. (1972) and is preferred to the more general and less specific "peloidal". Pelletoidal has the same meaning as "clotted micrite" or "structure grumeleuse" used by some authors. Pelletoidal structures have been illustrated from numerous fossil or modern buildups (see discussion in Pickard, 1992) and are prominent features of microbial mounds (James and Bourque, 1992) as well as sponge mounds (Bourque and Gignac, 1983; Bourque and Boulvain, 1993). Calcification is favoured by alkaline and reducing conditions; it therefore mainly occurs in the subsurface of the mat (Berner, 1969; Shinano, 1972; Morita, 1980; Mitterer and Carter, 1977). The diagenesis results from the combined action of a specific assemblage of functional groups of microbes (Van Gemerden, 1993). The crystal habit and mineralogy of the calcified products are determined by fluid flow rates (Given and Wilkinson, 1985) controlled by the viscosity of the growth medium (Buczynsky and Chafetz, 1990).

Micritic crusts are irregular, wavy or domal. The planar/wavy structures can grade upward to minute columns (Fig. 6.2).

(2) Skeletal microbiotic crusty elements of various taxonomic position are also tightly integrated in the stromatolitic crusts, including: calcareous sponges, bryozoas, foraminifera (specially coscinophragmatids), calcareous algae and annelids.

The fundamental mound architecture is therefore made of a macroskeletal precursor bound by stromatolitic accretions resulting in a skeletal/ stromatolitic supported framework subsequently infilled by muddy sediment. Evidence for primary internal cavities generated within the coral/stromatolitic framework, is provided by dense micritic or clear microsparitic geopetal sediments (Figs. $4.3,6.3,7.3)$. The primary cavities are characterized by their irregular roof (Fig. 7).

Micritic sediments filling the skeletal/stromatolitic framework is also present in organic borings. In some instances bioerosion was so active that the primary skeletal framework is preserved only as delicate anastomosing remnants corresponding to less than half of its estimated initial volume (see Fig. 4.2).

\subsection{Top and flank "breccias"}

Decimeter-sized elements including both lithoclasts of mound sediments (e.g. packstones with gastropods and algae) and coral colonies are present on the mound flanks, with thicknesses fluctuating from some decimeters to one meter. Although this facies is irregularly distributed, it is clearly oriented parallel to the depositional slope.

Centimeter-sized skeletal rubble consisting of corals, stromatoporoids and stromatolitic/skeletal elements frequently overlie the tops of the mounds. This facies represents the destructional and reworking phase of the primary skeletal community or even the lithified mound-structure itself; its thickness never exceeds $2-3 \mathrm{dm}$.

\section{Intermound sediments}

Intermound sediments are regarded either as time equivalent or postdepositional relative to the mound growth. In general, they overlap the mound flanks with a low angle and tend to fill intermound depressions with concave upward stratal geometries.

These consist of graded bioclastic deposits composed of coarse heterometric grainstones with rounded, abraded, sand-sized or gravel-sized components (Fig. 8). The coarser fraction is dominated by coral, stromatoporoid and rudist fragments and pieces of bioaggregations, i.e. broken fragments of polytaxic crusts including: bacinellid/microbial structures, foraminifera, calcareous algae, bryozoa. Foraminifera and dasyclads are rare but Boueina 

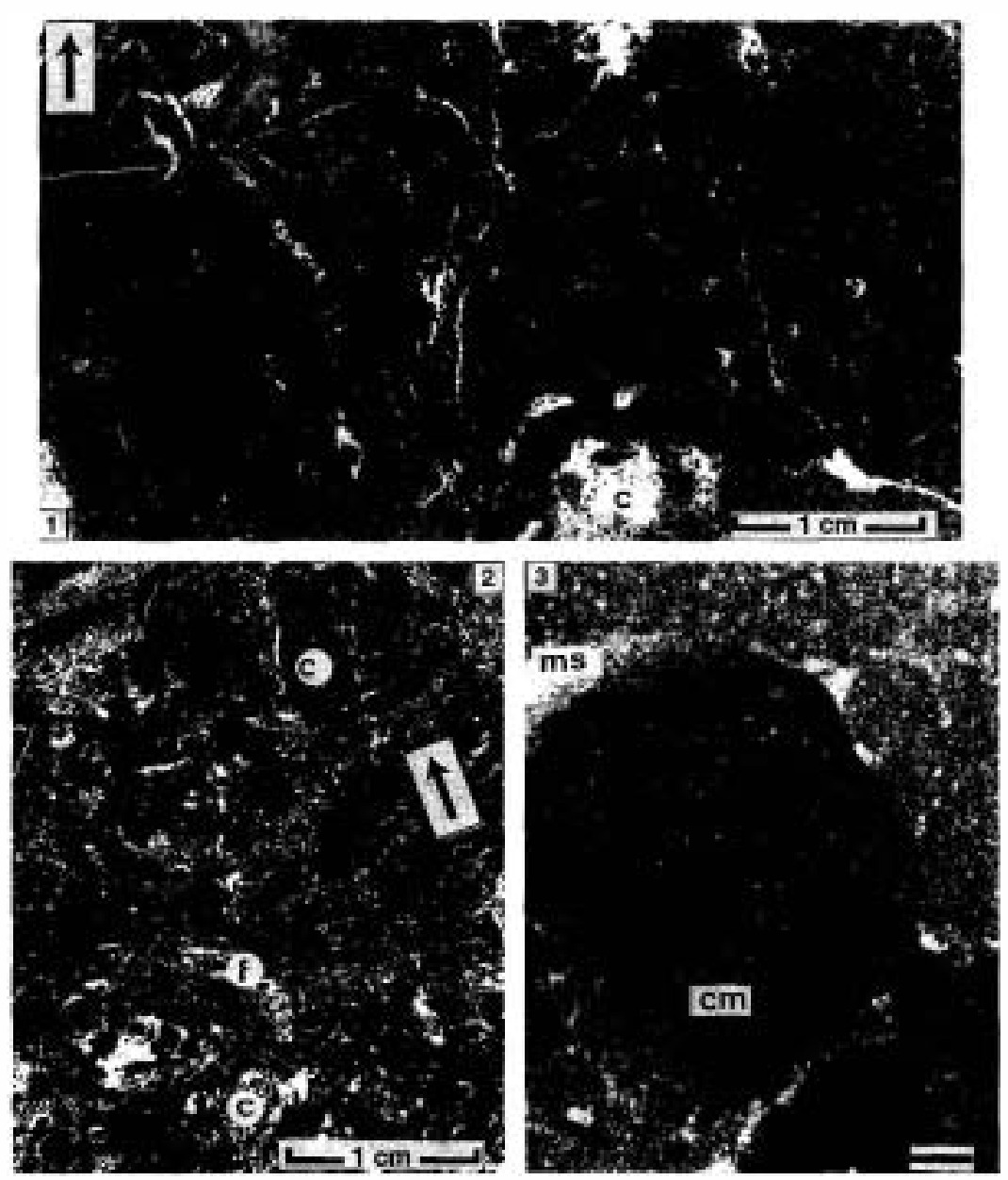

Fig. 6. Stromatolitic fabrics. 1. Laminated micritic mounds on bored coral (c) substrates. 2. Stromatolite/skeletal framework: $c=$ coral, $f=$ coscinophragmatid crust, $c=$ stromatolitic columns. Arrow indicates upward growth. 3. Clotted (microbial) micrite (cm) and "light micrite" or microsparitic surrounding sediment. Scale bar is $0.5 \mathrm{~mm}$.

debris and Terquemella are common. Locally shelly intercalations may possess stromatolitic encrustations forming in situ stabilized frameworks of minor vertical and lateral extent, which grade laterally into sandy sediments. Mechanical grain abrasion seems to be coeval with microbial alteration as shown by the widespread occurrence of well developed micritic grain coatings or crusts.

\section{Palaeoenvironment}

The biogenic mounds developed in very shallow water: in the infralittoral zone sensu Peres (1982) with photophile organisms, such as calcareous green algae (dasyclads) as well as hermatypic corals, rudists and chaetetids. Sciaphilic biota, like bryozoa and calcareous sponges are present, but played a limited role. Whereas hard to firm bottom, epifaunal, suspension feeding or symbiotic organisms formed the primary skeletal framework, the secondary framework was made by microbial and other microbenthic elements including autotrophic (i.e. photosynthetic and chemosynthetic) and heterotrophic organisms .

Vertical zonation is almost absent in the mounds. Nevertheless coarser grainy intercalations, lithoclasts and skeletal rubble are mainly 


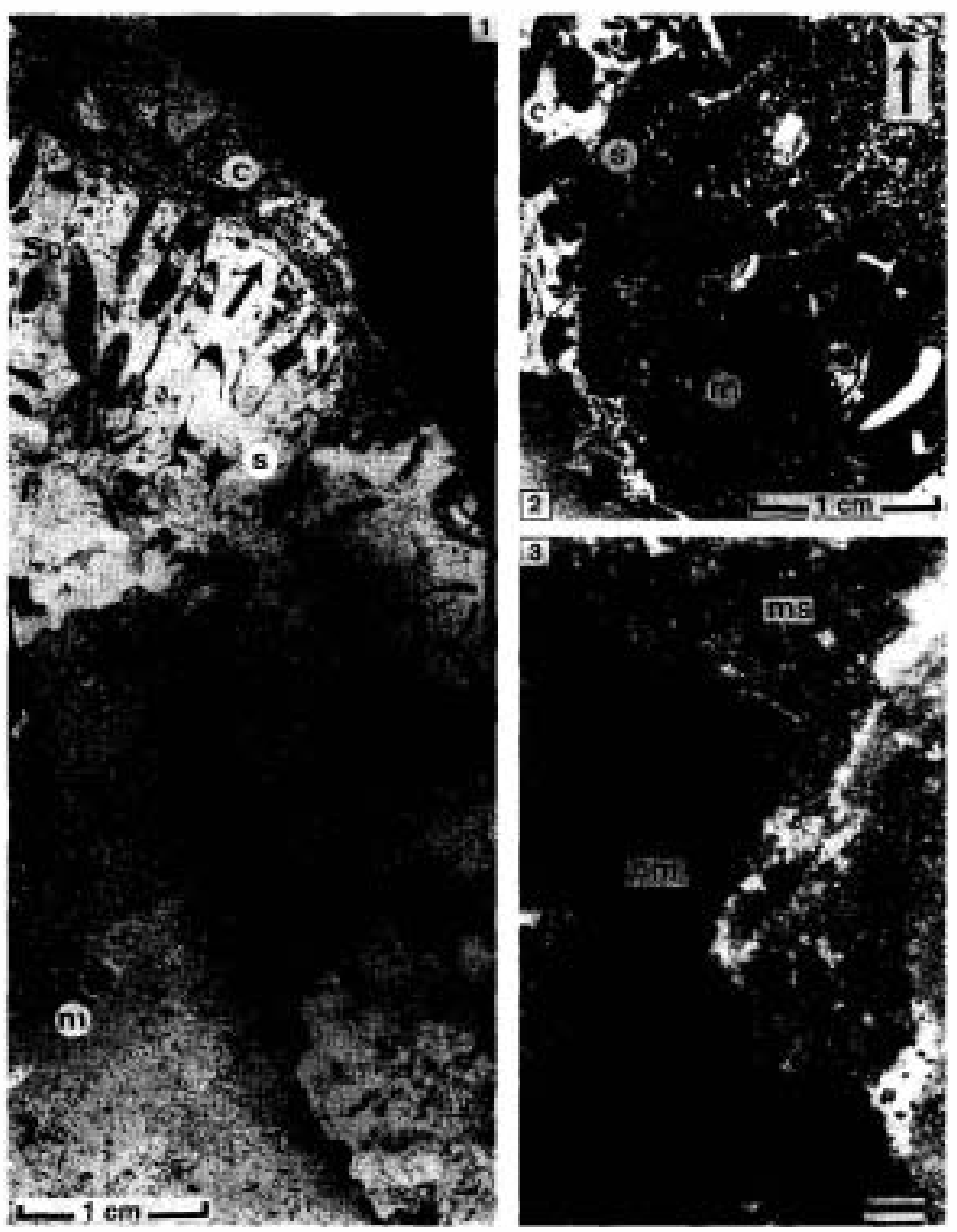

Fig. 7. Stromatolitic/skeletal framework and interval cavities. 1. $s=$ stromatolitic/skeletal crust with Nipponophycus (N), sponges $(s p)$ capped by a coral $(c)$ and stromatoporoid $(S t)$ crust. Polished slab. Arrow indicates upward growth. 2. Cavity filled with a micritic, finely bioclastic sediment $(m)$ surrounded by a dense microbial stromatolitic $(s)$ micrite coating a coral (densely bored) (c). 3. Clotted micrite (microbial) forming the stromatolitic framework; adjacent cavity is filled with a fine pelleted microsparitic sediment $(m s)$. Scale bar is $0.5 \mathrm{~mm}$.

concentrated at the top. This tendency suggests an increasing upward hydrodynamic instability correlated with a shallowing upward evolution. However, relatively high current energy sediments are not only recorded near the top but also on the mound flanks. This pattern shows that hydrodynamic gradients suggested by the biota and facies are not necessarily depth related.

Recurrent palaeoenvironmental changes during mound growth must be invoked for interpreting biological modifications from coral to stromatolitic communities. Such modifications could reflect fluctuations in nutrient availability, a process which has been documented from modern reefal environments. As shown by Birkeland (1988) and Hallock (1988), coral growth is inhibited by nutrient excess (i.e. eutrophic conditions), as clonal symbiotic organisms, corals can only thrive in oligo- to mesotrophic environments. Eutrophic conditions promote communities with small, fast 

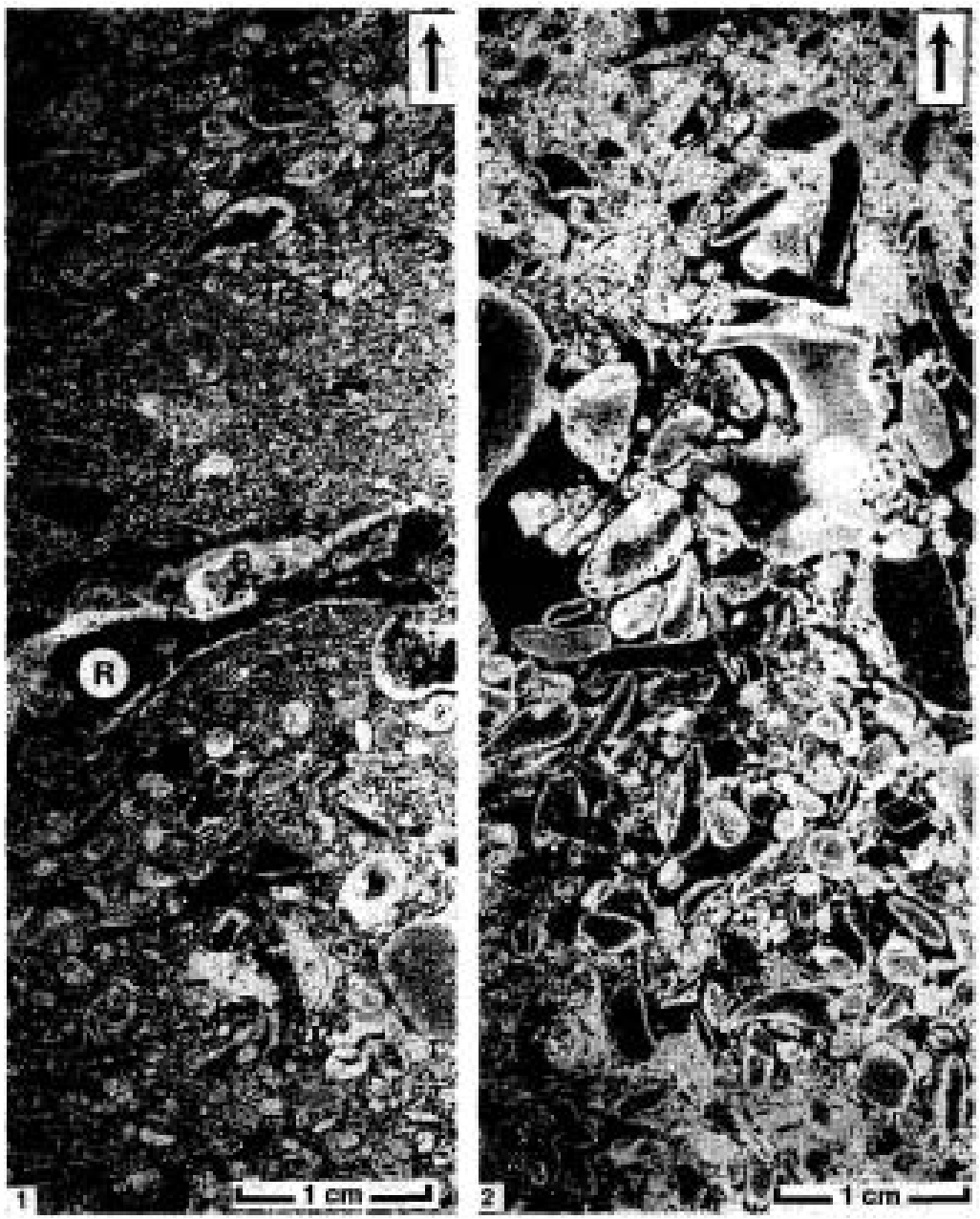

Fig. 8. Internnound sediments. 1. Graded bioclastic grainstone with rounded iso- or heterometric skeletal debris (mainly corals). Coarse elements (rudist $: R$ ) show bacinellid $(B)$ encrusting structures and micritic (white) coatings $(m)$. 2. Poorly sorted, coarse grainstone/packstone dominated by rudist and coral fragments. Arrows indicate way up.

growing organisms, especially algae, and increase bioerosion due, in particular, to boring bivalves, clionid sponges and cryptofauna in general (Hallock, 1988). Variations from near oligotrophic/mesotrophic to eutrophic conditions are therefore proposed to explain recurrent coral and stromatolitic biota. High nutrient levels also explain the high density of sponge and bivalve borings and subsequently an elevated rate of mud production.

The microbenthic communities show a distinct sequence of development which starts with a micritization or bacinellid boring and infilling of the colony. Subsequent stages correspond with coscinophragmatids and Polystrata with interspersed pelletoidal or micritic laminae, capped by a dense or clotted microbial micrite. Bryozoa, calcareous sponges and annelids are more frequent on the flanks of colonies. This situation is clearly light related: sciaphilic encrusters thrived mainly on the shaded flanks rather than on the illuminated tops. The entire sequence itself could also reflect light reduction related to increasing cryptic conditions (and restriction ?) generated by the 
continuous upward growth of the framework. Temporal variations in sedimentary suspensions could be inferred by considering the ability of the community members to thrive in high or low water turbity. Quartz grains are selectively incorporated in the coscinophragmatid walls, and are absent in the sedimentary matrix, suggesting that coscinophragmatids preferentially developed during phases of high water turbidity with particulate siliciclastic fluxes. Short term fluctuations in nutrient fluxes, correlated with the suspension variations, could be also envisaged. The relationships with adjacent intermound sediments show that episodic hydrodynamic events were able to rework and transport components of the mound epibiotic communities as well as some "deeper" parts of the structure, i.e. the organically bound, lithified basement. This suggests that the mounds were thriving in open marine agitated waters and that the external shape was probably influenced by hydrodynamic gradients concurring with the biological control.

\section{Importance of early diagenesis}

Early diagenesis was critically active at different levels and at different stages of mound growth.

First of all the hardening of the secondary stromatolitic framework reflects the early calcification of the microbial mats, as discussed above. The rigidity of the biological framework is documented by the existence of primary cavities, their subsequent sedimentary infilling and the occurrence of borings. Early diagenesis is also appealed to for interpreting the lithification of the infilling and entrapped muds, probably derived from nearby in situ bioerosion. The intensity of boring activity suggest a high production of fines. Clionid sponges are known to produce silt-grade "spongechips" (sensu Rütler and Rieger, 1973) while lithophagid bivalves produce mud grade elements (Adjas et al., 1990). The primary mineralogy of the corresponding substrates implies that the fines were mainly aragonitic, an interpretation fitting with the microsparitic habit (here considered a neomorphic microstructure derived from the recrystallization of the former aragonite) of the geopetal wackestones (Figs. 6.3, 7.3). Denser micritic sediments trapped in the biological framework could have had a different origin. Considering that during the Cretaceous the inorganic precipitation of carbonate was mainly calcitic (Sandberg, 1975, 1983), a significant part of the mud could have been primarily calcitic.

Early lithification can explain how mound growth would have been effective in shallow and relatively high energetic conditions.

\section{Comparisons}

The carbonate mounds described herein differ genetically from mud-mounds by the paucity of mud s.s.: the micritic fabrics are only partly mud derived. They also differ from microbial mounds because microbially-generated products are only partly involved in the mound formation. They finally differ from skeletally supported buildups by the lack of an actual skeletal framework, i.e. rigid interconnecting elements produced by macrobiotic organisms. Microbial accretions acting as binding agents are tightly associated with a wide variety of microscopic, skeletal, in situ components (foraminifera, calcareous algae, porostromata, etc.) involved in the framework. They possess many attributes regarded as characteristics of classical Palaeozoic mud-mounds (Pratt, 1982; Monty, 1990; Pickard, 1992; James and Bourque, 1992):

- their external shape, i.e. domal, is similar,

- they are flanked by intertonguing bioclastic sediments, the skeletal components of which are genetically related to those from the mound fauna,

- early lithification is extensive,

- microbial activity is very important.

Salient differences are nevertheless to be stressed: - vertical and lateral dimensions are smaller, even if some late Palaeozoic buildups can be of similar dimensions,

- skeletal, clonal organisms (corals and stromatoporoids) play a significant role as framework contributors, even if the mounds were, by no means, skeletal framework buildups,

- stromatactis structures are absent,

- soft deformation structures are lacking, 
-early fracturing has not been clearly documented,

- early marine cementation is not observed, as the result of complete occlusion of open space by muddy sediments,

-they developed in shallow water, whereas many of the Palaeozoic mounds are ascribed to relatively deeper settings.

The mounds show some similarities with Cretaceous occurrences. Corals with stromatolitic encrustations have been documented in cnidarian biostromes of the Barremian-Lower Aptian from SE France and the Upper Aptian from Algeria (Masse, 1979). In these instances corals acted as framebuilders and the stromatolitic crusts do not show any binding pattern; moreover the stromatolitic fabric is "monotaxic" and mainly micritic. The corresponding bodies were not topographically anomalous. The most similar described Cretaceous buildups are those recorded in the Aptian-Albian from northern Spain where different types of mud-mounds have been described (Pascal and Przybyla, 1989). The size and shape of the northern Spain buildups are often similar to those described here, though some are significantly larger, and the internal structure is mainly microbial (bacinellid and pelletoidal framework) with a reticulate network in which the cavities are infilled with a "light micrite". Early lithification is extensive and there is some evidence for early subaerial leaching.

In Recent settings, specially in coral reef ecosystems, stromatolitic/microbenthic skeletal crusts attached to coral frameworks are well documented. Micritic-pelletoidal and laminated organic coatings (= "matrix cement") have been described in fringing reefs of Panama (Macintyre, 1977), where multicyclic patterns of boring, sediment infilling and lithification can obscure the original skeletal coral frame. Similar crusts have also been described by Marshall (1983) in the southern Great Barrier reef, and Jones and Hunter (1991) at Grand Cayman.

In many of these instances the crusts were purely microbial as are those described in high energy reefs from French Polynesia (Montaggioni and Camoin, 1993). Polytaxic assemblages with well expressed sequences, e.g. corals, rhodolites, fora- minifera and microbialites, documented from the Late Pleistocene on Grand Cayman and San Salvador Island (Jones and Hunter, 1991) as well as from the Upper Miocene of Spain (Riding et al., 1991), are very similar to those from the Hauterivian mounds, but they are subordinate to coral in building the reef framework. Coral mudmounds recorded in the deep lagoon of New Caledonia island (Masse et al., 1989) are characterized by the dominance of mud and a coral framework, microbial products have not been recorded and there is no evidence of an inorganic lithification (at least on the mound surface). Shallow water mud-mounds, like those from Florida Bay, are different because their origin is mainly biodetrital (Bosence, 1990).

\section{Conclusions}

Shallow water, calcareous biogenic Hauterivian mounds are described from the northern edge of the Prebetic domain, in SE Spain. These mounds settled on and were embedded in bioclastic grainstones, and were capped by siliciclastic deposits. Their shape is low domed, with an horizontal basal surface. They are generally linked by their bases and their thickness is less than $10 \mathrm{~m}$. Their internal structure consists of a skeletal precursor (corals and stromatoporoids) with secondary microbial accretions containing a rich microbenthic skeletal association, resulting in a macroskeletal/stromatolitic rigid framework with intervening cavities. Different kinds of muds accumulated in the depressions or filled the primary cavities closing nearly all the available open space. Early lithification was extensive, enabling colonization by boring organisms (clionids and bivalves) which generated significant quantities of secondary carbonate mud. Organic coarse rubble and breccia are present on the tops and flanks of the biogenic mounds. Intermound sediments are coarse bioclastic sands genetically linked with the mound biological assemblages. Mounds grew in shallow water settings, with possible recurrent palaeoenvironmental changes, mainly nutrient fluxes. Short term modifications are also suggested for the microbial/ microskeletal communities, the sequence of which 
was controlled by light gradients related to particulate suspension fluctuations or increasing cryptic conditions.

Genetically the mounds are fundamentally biogenic comprising mixed macroskeletal and microbial/microskeletal components with subsequent additional sediment input. They are therefore comparable in some respects to certain Palaeozoic mud mounds from which they nevertheless depart in many aspects. They are also similar to some other Cretaceous biogenic reefs or mounds with a significant microbial control. Some striking similarities are also to be stressed with late Tertiary and Recent coral reef internal structures.

\section{Acknowledgements}

The authors thank P.A. Bourque and N.A.H. Pickard for helpful and constructive comments on this manuscript.

\section{References}

Adjas, A., Masse, J.P. and Montaggioni, L., 1990. Finegrained carbonates in nearly closed reef environments: Mataiva and Takapoto atolls, Central Pacific Ocean. Sediment. Geol., 67: 115-132.

Barattolo, F., 1991. Mesozoic and Cenozoic Marine benthic calcareous algae with particular regard to Mesozoic Dasycladaleans. In: R. Riding (Editor), Calcareous Algae and Stromatolites. Springer, Berlin, pp. 504-540.

Berner, R.A., 1969. Bacterial processes affecting the precipitation of calcium carbonate in sediments. Bermuda Biol. Stat. Res. Spec. Publ., 3: 183-187.

Birkeland, C., 1988. Second order ecological effects of nutrient input into coral communities. Galaxea, 7: 91-100.

Blatt, H., Middleton, G. and Murray, R., 1972. Origin of Sedimentary Rocks. Englewood Cliffs, $653 \mathrm{pp}$

Bosence, D.W.J., 1990. Biodetrital mud mounds of Florida Bay. In: 13th Int. Sedimentol. Congr., Nottingham, Abstr. Pap., pp. 55-56.

Bourque, P.A. and Boulvain, F., 1993. A model for the origin and petrogeneesis of the red stromatactis limestone of Palaeozoic carbonate mounds. J. Sediment. Petrol., 63(4): 607.

Bourque, P.A. and Gignac, H., 1983. Sponge-constructed Stromatactis mud mounds, Silurian of Gaspé, Québec. J. Sediment. Petrol., 53(2): 521-532.

Buczynski, C. and Chafetz, H.S., 1990. Habit of bacterially induced precipitates of calcium carbonate and the influence of medium viscosity on mineralogy. In: 13th Int. Sedimentol. Congr., Nottingham, Abstr. Pap., pp. 81-82.

Camoin, G., Bernet-Rollande, M.C. and Philip, J., 1988. Rudist-coral frameworks associated with submarine volcanism in the Maastrichtian of the Pachino area (Sicily). Sedimentology, 35: 123-138.

Camoin, G., 1990. Nature and origin of Cretaceous mud mounds. In: 13th Int. Sedimentol. Congr., Nottingham, Abstr. Pap., pp. 72-73.

Company, M., 1987. Los Ammonites del Valanginiense del sector oriental de las Cordilleras Béticas (SE de España). Thesis. Univ. Granada, 294 pp.

Fernández-Mendiola, P.A. and García-Mondéjar, J., 1989. Sedimentation of a Lower Cretaceous (Aptian) coral mound complex, Zaraya Mountains, northern Spain. Geol. Mag., 124(4): 423-434.

Fourcade, E., 1970. Le Jurassique et le Crétacé aux confins des Chaînes Bétiques et Ibériques. Thesis. Univ. Paris VI, 427 pp.

García-Mondéjar, J. and Fernández-Mendiola, P.A., 1990. Comparative study of carbonate mounds in the context of system tracts analysis: Albian of Soba, northern Spain. In: 13th Int. Sedimentol. Congr., Nottingham, Abstr. Pap., p. 181.

Given, R.K. and Wilkinson, B.H., 1985. Kinetic control of morphology, composition and mineralogy of abiotic sedimentary carbonates. J. Sediment. Petrol., 55: 109-119.

Hallock, P., 1988. The role of nutrient availability in bioerosion: consequences to carbonate buildups. Palaeogeogr. Palaeoclimatol. Palaeoecol., 63: 275-291.

James, N.P. and Bourque, P.A., 1992. Reefs and mounds. In: R. Walker and N.P. James (Editors), Facies Models Response to Sea-level Change. Geol. Assoc. Can., 17: 323-347.

Jansa, L.F., Termier, G. and Termier, H., 1982. Les biohermes à algues, spongiaires et coraux des series carbonatées de la flexure bordière du "paleoshelf" au large du Canada oriental. Rev. Micropaleontol., 25(3): 181-219.

Jones, B. and Hunter, I.G., 1991. Corals to rhodolites to microbialites. A community replacement sequence indicative of regressive conditions. Palaios, 6(1): 54-66.

Macintyre, I.G., 1977. Distribution of submarine cements in a modern caribbean fringing reef, Galeta Point, Panama. J. Sediment. Petrol., 47(2): 503-516.

Marshall, J.F., 1983. Submarine cementation in a high energy platform reef: One Tree Reef, southern Great Barrier Reef. J. Sediment. Petrol., 53: 1133-1149.

Mas, J.R., 1981. El Cretácico inferior de la región noroccidental de la provincia de Valencia. Seminar. Estratigr. Ser. Monogr., $8,408 \mathrm{pp}$.

Mas, J.R., Alonso, A. and Melendez, N., 1982. El Cretácico basal "Weald" de la Cordillera Ibérica suroccidental (NW de la provincia de Valencia y E de la de Cuenca). Cuad. Geol. Ibér., 8: 309-335.

Masse, J.P., 1979. Schizophytoïdes du Crétacé inferieur. Caracteristiques et signification ecologique. Bull. Cent. Rech. Explor. Prod. Elf-Aquit., 3(2): 685-703.

Masse, J.P. and Philip, J., 1981. Cretaceous coral-rudist 
buildups of France. Soc. Econ. Paleontol. Mineral. Spec. Pub., 30: 399-426.

Masse, J.P., Adjas, A. and Thomassin, B.A., 1989. Modern lagoonal coral mud-mounds: the "Gail Bank" example (SW New Caledonia Island Lagoon). Annu. Meet. Int. Soc. Reef Stud., Marseille, Abstr., pp. 101-102.

Masse, J.P., 1992. The Lower Cretaceous Mesogean benthic ecosystems: palaeoecologic aspects and palaeobiogeographic implications. Palaeogeogr. Palaeoclimatol. Palaeoecol., 91: 331-345.

Masse, J.P., Arias, C. and Vilas, L., 1993a. Zittelina hispanica et Suppiluliumaella minuta dasycladales nouvelles de l'Hauterivien du Sud-Est de l'Espagne. Rev. Micropaleontol., 36(4): 293-300.

Masse, J.P., Arias, C. and Vilas, L., 1993 b. Caracterización litoestratigráfica y bioestratigráfica del Valanginiense superior-Hauteriviense inferior en el Prebético de la zona septentrional de Murcia. Rev. Esp. Micropaleontol., 25(3): 123-136.

Mitterer, R.M. and Carter, P., 1977. Some analytical and experimental data on organic-carbonate interaction. Proc. 3rd Int. Coral Reef Symp., Miami, pp. 541-547.

Monty, C.L.V., 1990. The role of microbes in the genesis and diagenesis of mud mounds. In: 13th Int. Sedimentol. Congr., Nottingham, Abstr. Pap., pp. 365-366.

Montaggioni, L. and Camoin, G., 1993. Stromatolites associated with coralgal communities in Holocene high-energy reefs. Geology, 21: 149-152.

Morita, R.Y., 1980. Calcite precipitation by marine bacteria. Geomicrobiol. J., 2(1): 63-82.

Negra, M.E.H. and Purser, B.H., 1989. Les monticules senoniens à Rudistes du Jebel el Kebar, Tunisie Centrale. Anatomie, diagenese et geometrie. Geol. Mediterr., 16: 99-119.

Pascal, A. and Przybyla, A., 1989. Processus biosedimentaires et diagenetiques precoces dans les mud-mounds (thrombolitemounds) urgoniens d'Espagne du Nord (Aptien-Albien) et leur signification. Geol. Mediterr., 16: 171-184.

Peres, J.M., 1982. Ocean managements. In: O. Kinne (Editor), Marine Ecology. Wiley, New York, 5, 1, pp. 9-45.

Pérez del Campo, P. and Zavala, L., 1982. Los primeros episodios de la sedimentación cretácica en el extremo suroriental del Sistema Ibérico. Cuad. Geol. Ibér., 8: 411-429.
Pickard, N.A.H., 1992. Depositional controls of Lower Carboniferous microbial buildups eastern Midland Valley of Scotland. Sedimentology, 39: 1081-1100.

Pratt, B.R., 1982. Stromatolitic framework of carbonate mud mounds. J. Sediment. Petrol., 52: 1203-1227.

Riding, R., 1991. Classification of microbial carbonates. In: R. Riding (Editor.), Calcareous Algae and Stromatolites. Springer, Berlin, pp. 21-51.

Riding, R., Martín, J.M. and Braga, J.C., 1991. Coralstromatolite reef framework, Upper Miocene, Almeria, Spain. Sedimentology, 38: 799-818.

Rützler, K. and Rieger, G., 1973. Sponge burrowing: fine structure of Cliona lampa penetrating calcareous substrata. Mar. Biol., 50: 144-162.

Sandberg, P.A., 1975. New interpretations of Great Salt Lake ooids and of ancient non skeletal carbonate mineralogy. Sedimentology, 22(4): 497-537.

Sandberg, P.A., 1983. An oscillating trend in Phanerozoic nonskeletal carbonate mineralogy. Nature, 305: 19-22.

Schulte, S., Davaud, E. and Wernli, R., 1993. Les bioconstructions à foraminifères de l'Urgonien du massif du Haut-Giffre (Hte Savoie, France). Bull. Soc. Geol. Fr., 164(5): 675-682.

Shinano, H., 1972. Studies of marine microorganisms taking part in the precipitation of calcium carbonate. IV. A taxonomic study of marine bacteria taking part in the precipitation of calcium carbonate. Bull. Jap. Soc. Sci. Fish., 38(7): 825-832.

Scott, R.W., 1988. Evolution of Late Jurassic and Early Cretaceous reef biotas. Palaios, 3: 184-193.

Scott, R.W., Fernandez-Mendiola, P.A., Gili, E. and Simo, A., 1990. Persistence of coral-rudist reefs into the Late Cretaceous. Palaios, 5: 98-110.

Van Gemerden, H., 1993. Microbial mats: a joint venture. Mar. Geol., 113: 3-25.

Vilas, L., Arias, C. and Garcia, A., 1982. El paso del dominio ibérico al dominio bético en la zona suroriental de Albacete: la Sierra de la Oliva. In: El Cretácico de la parte central y oriental de la provincia de Albacete. Univ. Complutense, Madrid, pp. 51-72.

Wernli, R. and Schulte, S., 1993. Bdelloidina urgonensis n. sp., un foraminifère constructeur de biohermes dans l'Urgonien de Haute-Savoie (France). Eclogae Geol. Helv., 86(2): 529-541. 